International Journal of Engineering \& Technology, $7(2.14)(2018) 281-285$
International Journal of Engineering \& Technology
SPC
Website: www.sciencepubco.com/index.php/IJET
Research Paper

\title{
Technique for Order Preference by Similarity to Ideal Solution as Decision Support Method for Determining Employee Performance of Sales Section
}

\author{
V N S Lestari ${ }^{1 *}$, Hardianto Djanggih ${ }^{2}$, Aan Aswari ${ }^{3}$, Nasrun Hipan ${ }^{4}$, A P U Siahaan ${ }^{5}$ \\ ${ }^{I}$ Faculty of Economic and Business, Universitas Dr. Soetomo, Surabaya, Indonesia \\ ${ }^{2}$ Universitas Tompotika Luwuk Banggai, Sulawesi Tengah, Indonesia \\ ${ }^{3}$ Universitas Muslim Indonesia, Makassar, Indonesia \\ ${ }^{4}$ Universitas Muhammadiyah Luwuk Banggai, Sulawesi Tengah, Indonesia \\ ${ }^{5}$ Faculty of Science and Technology, Universitas Pembangunan Panca Budi, Medan, Indonesia \\ *Corresponding author E-mail: venugra@ unitomo.ac.id
}

\begin{abstract}
Employees are the backbone of corporate activities and the giving of bonuses, job titles and allowances to employees to motivate the work of employees is very necessary, salesman on the company very much and to find the best salesman cannot be done manually and for that required the implementation of a system in this decision support system by applying the TOPSIS method, it is expected with the implementation of TOPSIS method the expected results of top management can be fulfilled.
\end{abstract}

Keywords: Decision Support System, TOPSIS, Selection Sales

\section{Introduction}

Selection is an activity of the company to select the right employees to occupy a particular position offered by management[1]-[3] At the same time as a tool to eliminate or to not choose other employees who seek to occupy the position offered and tailored to a job within the organization or company [4], [5]. The selection process is a systematic process undertaken to ensure that those who are accepted are deemed most appropriate, either by established criteria or by the amount required[6]-[10]. Weak selection process implemented in the company will result in low morale, work discipline, and loyal attitude of employees in implementing the company's goals[11]-[13].

PT. XYZ is a company that acts as a distributor of Drug Products from several drug suppliers, limitations faced by PT. XYZ is choosing an accomplished salesman among those who deserve to get the achievement title for promotion and bonuses. To perform and simplify the selection process, then applied method of decision support system. One method of decision support system that can be applied is TOPSIS method that apply the concept of completion with Fuzzy Multi Criteria Decision Making[14], [15]. Fuzzy Multi Criteria Decision Making is a decision making process contained in the TOPSIS method considering several alternatives and criteria in a fuzzy situation[16]-[20].

\section{Methodology}

Basically Decision Support System (DSS) is a further development of computerized management information system designed in such a way that is interactive with the wearer[15], [21], [22]. This interactive nature is intended to facilitate the integration be- tween the various components in the decision-making process such as procedures, policies, analytical techniques, and experience and managerial insight to establish a flexible decision framework[23], [24].

Decision Support System is a computer-based information system that generates various decision alternatives to assist management in handling various structured or unstructured problems using data and models [25]-[33]. Computer-based word is a keyword, because it is almost impossible to build a DSS without using a computer as a tool, especially for storing data and managing models. Here are the characteristics and capabilities of decision support systems obtained from various references[20], [34], [35]:

a. Decision Support System Characteristics

1) Support all organizational activities

2) Support multiple interacting decisions

3) Can be used repeatedly and is constant

4) There are two main components, namely data and models

5) Use both external and internal data

6) Have the ability of What-if Analysis and Goal Seeking Analysis

7) Using some quantitative models

b. Decision Support System capabilities

1) Supporting management decision making in handling problems semi structured and unstructured.

2) Assist managers at various levels of management, ranging from upper management to lower level management.

3) Supports group and individual decision making.

4) Supports interdependent and consecutive decisionmaking.

5) Supporting the stages of decision-making include intelligence, design, choice, and implementation. 
6) Support the various forms of decision-making and decision-making processes.

7) Ability to adapt at any time and be flexible.

8) Ease of system interaction.

9) Improving effectiveness in decision-making rather than efficiency.

10) Easy to develop by expert users.

11) Modeling ability and decision-making analysis.

12) Ease of accessing various sources and data formats.

In addition to the various Characteristics and Abilities as noted above, DSS also has some limitations as follows:

a. There are some management abilities and human talents that cannot be modeled, so the models that exist in the system do not all reflect the real problem.

b. The ability of a DSS is limited to the knowledge that it possesses (basic knowledge and basic model).

c. The processes that can be performed by the DSS usually depend also on the software capabilities it uses.

d. DSS does not have the ability of intuition as it is owned by humans. Because no matter how sophisticated a DSS is, it's just a collection of hardware, software and operating systems not equipped with the ability to think.

The TOPSIS method is based on the concept that the best chosen alternative not only has the shortest distance from the ideal solution, but also has the longest distance from the ideal solution. This concept is widely used in some MADM models to solve practical decision problems[36], [37].

This is because the concept is simple and easy to understand, computing is efficient, and has the ability to measure the relative performance of decision alternatives in simple mathematical form. As for the steps in solving a Multi Attribute Decision Making (MADM) case with TOPSIS[38]:

a. Make a normalized decision matrix.

b. Make a decision matrix that is normally weighted.

c. Determine the matrix of positive ideal solutions and the matrix of the ideal solution.

d. Determine the distance between the value of each alternative with a matrix of positive ideal solutions and the ideal negative solution matrix.

e. Determine the preference value for each alternative. TOPSIS requires performance rating of each alternative $\mathrm{Ai}$ on loyal $\mathrm{C}_{\mathrm{j}}$ normalized criteria.

\section{Results and Discussion}

The process of applying the Fuzzy Multi Criteria Decision Making method in performing alternative performance appraisal as follows: a. Weighting Criteria

Determining the ranking of each alternative, then the first determination of the importance weight of each criterion $\left(\mathrm{W}_{\mathrm{j}}\right)$. The determination of the importance weight of each criterion $\left(\mathrm{W}_{\mathrm{j}}\right)$ is formed in Table 1 below.

Table.1: Criteria Weight Value $\left(\mathrm{W}_{\mathrm{j}}\right)$

\begin{tabular}{|l|c|}
\hline \multicolumn{1}{|c|}{ Criteria } & Weight Value \\
\hline Data Sales & 4 \\
\hline Absence & 3 \\
\hline Number of Visits & 2 \\
\hline
\end{tabular}

b. Initial Data of each alternative

From the criterion data already started, the next step is to determine the match rating as Table 2 below:

Table.2: Alternative

\begin{tabular}{|l|c|c|c|}
\hline \multirow{2}{*}{ Alternative } & \multicolumn{3}{|c|}{ Criteria } \\
\cline { 2 - 4 } & $\mathrm{C} 1$ & $\mathrm{C} 2$ & $\mathrm{C} 3$ \\
\hline Alternative 1 & 3 & 2 & 3 \\
\hline Alternative 2 & 2 & 2 & 3 \\
\hline Alternative 3 & 4 & 1 & 3 \\
\hline
\end{tabular}

After the initial data obtained from each alternative, then begins calculation of Fuzzy Multi Criteria Decision Making method by building a decision matrix. In the decision matrix, the matrix column expresses the attributes of the existing criteria, while the matrix line represents the alternative. The decision matrix refers to the alternative $m$ that will be evaluated on the basis of $n$ criteria. Decision matrix can be seen in table 3 that is:

Table.3: Decision Matrix

\begin{tabular}{|l|c|c|c|}
\multirow{2}{*}{ Alternative } & \multicolumn{3}{|c|}{ Criteria } \\
\cline { 2 - 4 } & $\mathrm{C} 1$ & $\mathrm{C} 2$ & $\mathrm{C} 3$ \\
\hline Alternative 1 & $\mathrm{X}_{11}$ & $\mathrm{X}_{12}$ & $\mathrm{X}_{13}$ \\
\hline Alternative 2 & $\mathrm{X}_{21}$ & $\mathrm{X}_{22}$ & $\mathrm{X}_{23}$ \\
\hline Alternative 3 & $\mathrm{X}_{31}$ & $\mathrm{X}_{32}$ & $\mathrm{X}_{33}$ \\
\hline
\end{tabular}

Next is to create a normalized $\mathrm{R}$ decision matrix whose function is to minimize the range of data, with the aim of making it possible to calculate Fuzzy Multi Criteria Decision Making.

Table.4: Matrix Normalized

\begin{tabular}{|l|c|c|c|}
\hline & \multicolumn{3}{|c|}{ Criteria } \\
\hline A1 & $\frac{x_{11}}{\sqrt{x_{11}^{2}+x_{21}^{2}+x_{31}^{2}}}$ & $\frac{x_{12}}{\sqrt{x_{12}^{2}+x_{22}^{2}+x_{32}^{2}}}$ & $\frac{x_{13}}{\sqrt{x_{13}^{2}+x_{23}^{2}+x_{33}^{2}}}$ \\
\hline A2 & $\frac{x_{21}}{\sqrt{x_{11}^{2}+x_{21}^{2}+x_{31}^{2}}}$ & $\frac{x_{22}}{\sqrt{x_{12}^{2}+x_{22}^{2}+x_{32}^{2}}}$ & $\frac{x_{23}}{\sqrt{x_{13}^{2}+x_{23}^{2}+x_{33}^{2}}}$ \\
\hline A3 & $\frac{x_{31}}{\sqrt{x_{11}^{2}+x_{21}^{2}+x_{31}^{2}}}$ & $\frac{x_{32}}{\sqrt{x_{12}^{2}+x_{22}^{2}+x_{32}^{2}}}$ & $\frac{x_{33}}{\sqrt{x_{13}^{2}+x_{23}^{2}+x_{33}^{2}}}$ \\
\hline
\end{tabular}

So the result of normalized matrix is seen in the following calculation:

A

(Criteria 1)

$$
\begin{gathered}
\frac{3}{\sqrt{3^{2}+2^{2}+4^{2}}} \\
\frac{3}{\sqrt{9+4+16}} \\
\frac{3}{\sqrt{29}} \\
\frac{3}{5.385} \\
0.56
\end{gathered}
$$

(Criteria 2)

$$
2
$$

$$
\begin{gathered}
\sqrt{2^{2}+2^{2}+1^{2}} \\
\frac{2}{\sqrt{4+4+1}} \\
\frac{2}{\sqrt{9}} \\
\frac{2}{3} \\
0.67
\end{gathered}
$$

(Criteria 3)

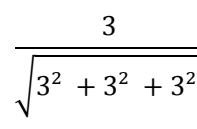

$$
\begin{gathered}
\frac{3}{\sqrt{9+9+9}} \\
\frac{3}{\sqrt{27}} \\
\frac{3}{5.196} \\
\mathbf{0 . 5 8}
\end{gathered}
$$

A2 (Criteria 1)

$$
\begin{gathered}
\frac{2}{\sqrt{3^{2}+2^{2}+4^{2}}} \\
\frac{2}{\sqrt{9+4+16}} \\
\frac{2}{\sqrt{29}}
\end{gathered}
$$




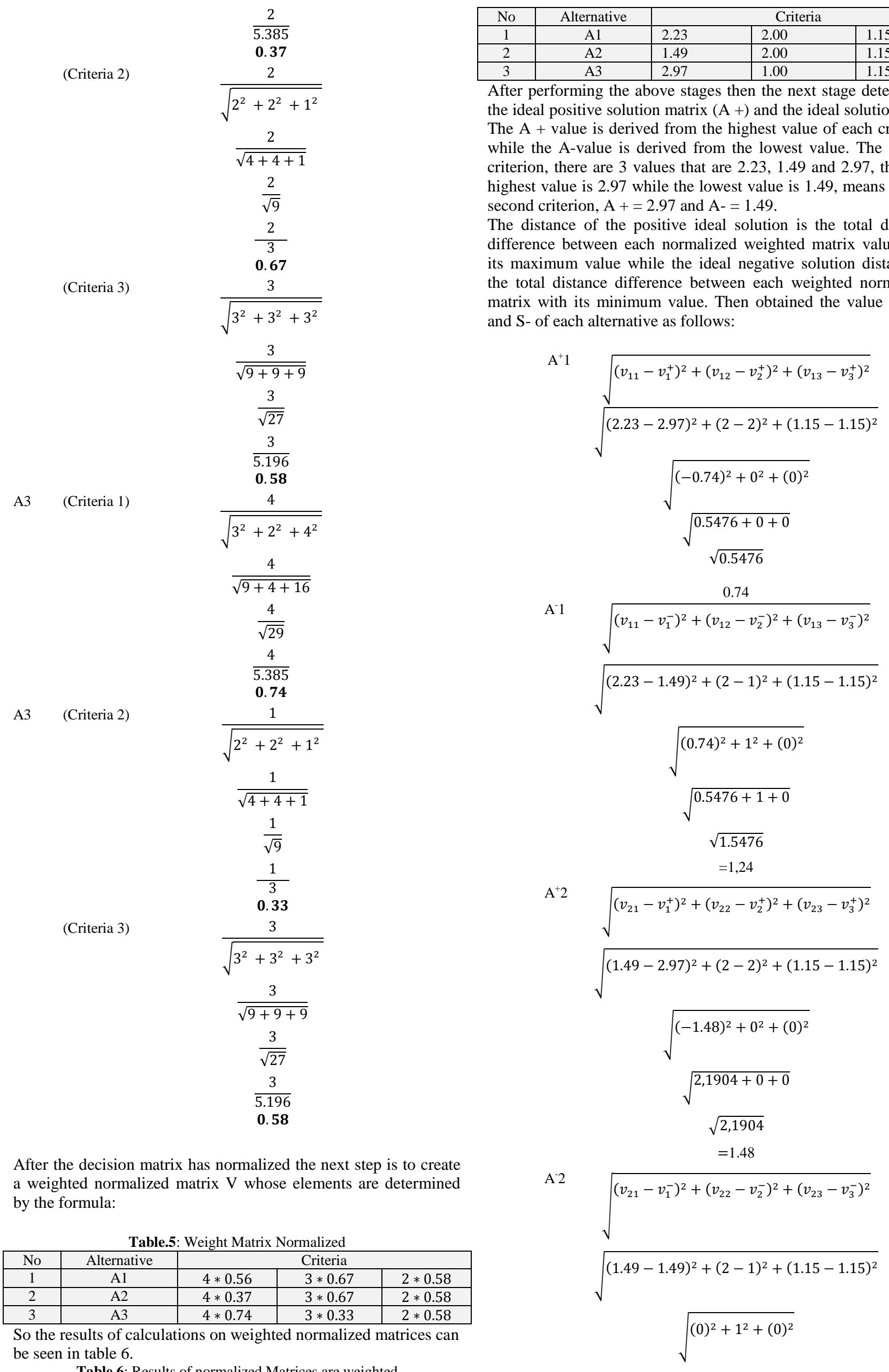




\section{$\sqrt{0+1+0}$}

$\sqrt{1}$

$=1$

$\mathrm{A}^{+} 3$

$$
\begin{gathered}
\sqrt{\left(v_{31}-v_{1}^{+}\right)^{2}+\left(v_{32}-v_{2}^{+}\right)^{2}+\left(v_{33}-v_{3}^{+}\right)^{2}} \\
\sqrt{(2.97-2.97)^{2}+(1-2)^{2}+(1.15-1.15)^{2}} \\
\sqrt{(0)^{2}+(-1)^{2}+(0)^{2}} \\
\sqrt{0+1+0}
\end{gathered}
$$$$
\sqrt{1}
$$

$=1$

$\mathrm{A}^{-3}$

$$
\begin{gathered}
\sqrt{\left(v_{31}-v_{1}^{-}\right)^{2}+\left(v_{32}-v_{2}^{-}\right)^{2}+\left(v_{33}-v_{3}^{-}\right)^{2}} \\
\sqrt{(2.97-1.49)^{2}+(1-1)^{2}+(1.15-1.15)^{2}} \\
\sqrt{(1.48)^{2}+(0)^{2}+(0)^{2}} \\
\sqrt{2.1904+0+0} \\
\sqrt{2.1904} \\
=1,48
\end{gathered}
$$

After calculating $\mathrm{S}+$ and $\mathrm{S}$ - then the next step is calculating the proximity relative to the ideal solution (C), so the result of the $\mathrm{C}$ value of each alternative can be calculated as follows:

$$
\begin{aligned}
& \text { A1 } \quad \mathrm{C}_{1}=\frac{1.24}{1.24+0.74} \\
& 1=\frac{1.24}{1.98} \\
&= 0.63 \\
& \mathrm{~A} 2 \quad \mathrm{C}_{2}=\frac{1}{1+1.48} \\
& 2=\frac{1}{2.48} \\
&=0.40 \\
& C_{3}=\frac{1.48}{1.48+1} \\
& 3=\frac{1.48}{2.48} \\
&=0.60
\end{aligned}
$$

So at the value of each alternative can be sorted to know which alternative is best.

\section{Conclusion}

The application of TOPSIS method to determine the best salesman can run well, positive and negative ideal concept can give comparison between each alternative of each criterion, this research is far from good and the results obtained also only based on one method only and for further development can be combined or compared with other methods to obtain varying results

\section{References}

[1] S. Robbins, "Organizational Behavior," in Zhurnal Eksperimental'noi i Teoreticheskoi Fiziki, 2013, p. 676.

[2] C. Truss, A. Shantz, E. Soane, K. Alfes, and R. Delbridge, "Employee engagement, organisational performance and individual well-being: Exploring the evidence, developing the theory," International Journal of Human Resource Management, vol. 24, no. 14, pp. 2657-2669, 2013.

[3] T. Suryanto, R. Rahim, and A. S. Ahmar, "Employee Recruitment Fraud Prevention with the Implementation of Decision Support System," J. Phys. Conf. Ser., vol. 1028, no. 1, p. 012055, Jun. 2018.

[4] K. Jiang, D. P. Lepak, K. Han, Y. Hong, A. Kim, and A. L. Winkler, "Clarifying the construct of human resource systems: Relating human resource management to employee performance," Hum. Resour. Manag. Rev., vol. 22, no. 2, pp. 73-85, 2012.

[5] R. Nasriyah, Z. Arham, and Q. Aini, "Profile matching and competency based human resources management approaches for employee placement decision support system (case study)," Asian J. Appl. Sci., vol. 9, no. 2, pp. 75-86, 2016.

[6] A. Yanie et al., "Web Based Application for Decision Support System with ELECTRE Method," J. Phys. Conf. Ser., vol. 1028, no 1, p. 012054, Jun. 2018.

[7] R. Rahim et al., "TOPSIS Method Application for Decision Support System in Internal Control for Selecting Best Employees," J. Phys. Conf. Ser., vol. 1028, no. 1, p. 012052, Jun. 2018.

[8] A. Alesyanti, R. Ramlan, H. Hartono, and R. Rahim, "Ethical decision support system based on hermeneutic view focus on social justice," Int. J. Eng. Technol., vol. 7, no. 2.9, pp. 74-77, 2018.

[9] Y. Rossanty, D. Hasibuan, J. Napitupulu, M. Dharma, and T. Putra, "Composite performance index as decision support method for multi case problem," Int. J. Eng. Technol., vol. 7, no. 2.9, pp. 33-36, 2018.

[10] S. H. Sahir, R. Rosmawati, and R. Rahim, "Fuzzy model tahani as a decision support system for selection computer tablet," Int. J. Eng. Technol., vol. 7, no. 2.9, pp. 61-65, 2018.

[11] T. Simanihuruk et al., "Hesitant Fuzzy Linguistic Term Sets with Fuzzy Grid Partition in Determining the Best Lecturer," Int. J. Eng. Technol., vol. 7, no. 2.3, pp. 59-62, 2018.

[12] M. D. T. P. Nasution et al., "Decision Support Rating System with Analytical Hierarchy Process Method," Int. J. Eng. Technol., vol. 7 no. 2.3 , pp. $105-108,2018$

[13] A. Indahingwati, M. Barid, N. Wajdi, D. E. Susilo, N. Kurniasih, and R. Rahim, "Comparison Analysis of TOPSIS and Fuzzy Logic Methods On Fertilizer Selection," Int. J. Eng. Technol., vol. 7, no. 2.3 , pp. 109-114, 2018.

[14] P. harliana and R. Rahim, "Comparative Analysis of Membership Function on Mamdani Fuzzy Inference System for Decision Making," J. Phys. Conf. Ser., vol. 930, no. 1, p. 012029, Dec. 2017.

[15] R. Risawandi and R. Rahim, "Study of the Simple Multi-Attribute Rating Technique For Decision Support," Int. J. Sci. Res. Sci. Technol., vol. 2, no. 6, pp. 491-494, 2016.

[16] G. Kabir and M. A. A. Hasin, "Comparative analysis of TOPSIS and Fuzzy TOPSIS for the evaluation of travel website service quality," Int. J. Qual. Res., vol. 6, no. 3, pp. 169-185, 2012.

[17] B. (Kiran) Bulgurcu, "Application of TOPSIS Technique for Financial Performance Evaluation of Technology Firms in Istanbul Stock Exchange Market," Procedia - Soc. Behav. Sci., vol. 62, pp. 1033-1040, 2012.

[18] A. M. Yaakob and A. Gegov, "Interactive TOPSIS Based Group Decision Making Methodology Using Z-Numbers," Int. J. Comput. Intell. Syst., vol. 9, no. 2, pp. 311-324, 2016.

[19] A. Łatuszyńska, "Multiple-Criteria Decision Analysis Using Topsis Method For Interval Data In Research Into The Level Of Information Society Development," Folia Oeconomica Stetin., vol. 13, no. 2, pp. 63-76, Jan. 2014.

[20] C. H. Primasari, R. Wardoyo, and A. K. Sari, "Integrated AHP, Profile Matching, and TOPSIS for selecting type of goats based on environmental and financial criteria," Int. J. Adv. Intell. Informatics, vol. 4, no. 1, pp. 28-39, Mar. 2018.

[21] A. A. Esfahani et al., "An evaluation model for the implementation of hospital information system in public hospitals using multicriteria-decision-making (MCDM) approaches," Int. J. Eng. Technol., vol. 7, no. 1, p. 1, Dec. 2017.

[22] M. Min, "A rule based expert system for analysis of mobile sales data on fashion market," in 2013 International Conference on Information Science and Applications, ICISA 2013, 2013.

[23] D. Napitupulu, M. Syafrullah, R. Rahim, A. Amar, and Y. Sucahyo, "Content validity of critical success factors for e-Government 
implementation in Indonesia," IOP Conf. Ser. Mater. Sci. Eng., vol. 352, p. 012058, May 2018.

[24] K. Adiyarta, D. Napitupulu, H. Nurdianto, R. Rahim, and A. Ahmar, "User acceptance of E-Government Services Based on TRAM model," IOP Conf. Ser. Mater. Sci. Eng., vol. 352, p. 012057, May 2018.

[25] J. Papathanasiou, N. P. B, T. Bournaris, and B. Manos, "A Decision Support System for Multiple Criteria Alternative Ranking Using TOPSIS and VIKOR: A Case Study on Social Sustainability in Agriculture," ICDSST, vol. 2, pp. 3-15, 2016

[26] R. Rahim, A. S. Ahmar, A. P. Ardyanti, and D. Nofriansyah, "Visual Approach of Searching Process using Boyer-Moore Algorithm," J. Phys. Conf. Ser., vol. 930, no. 1, p. 012001, Dec. 2017.

[27] R. Rahim, I. Zulkarnain, and H. Jaya, "A review: search visualization with Knuth Morris Pratt algorithm," in IOP Conference Series: Materials Science and Engineering, 2017, vol. 237, no. 1, p. 012026.

[28] P. He, L. Chen, and X. H. Xu, "Fast C4.5," in Proceedings of the Sixth International Conference on Machine Learning and Cybernetics, ICMLC 2007, 2007, vol. 5, pp. 2841-2846.

[29] R. Rahim, S. Nurarif, M. Ramadhan, S. Aisyah, and W. Purba "Comparison Searching Process of Linear, Binary and Interpolation Algorithm,” J. Phys. Conf. Ser., vol. 930, no. 1, p. 012007, Dec. 2017.

[30] R. Rahim, I. Zulkarnain, and H. Jaya, "Double hashing technique in closed hashing search process," IOP Conf. Ser. Mater. Sci. Eng., vol. 237 , no. 1 , p. 012027 , Sep. 2017.

[31] D. U. Sutiksno, A. S. Ahmar, N. Kurniasih, E. Susanto, and A Leiwakabessy, "Forecasting Historical Data of Bitcoin using ARIMA and $\alpha$-Sutte Indicator," J. Phys. Conf. Ser., vol. 1028, no. 1 , p. 012194, 2018.

[32] A. S. Ahmar, A. Rahman, A. N. M. Arifin, and A. A. Ahmar, "Predicting movement of stock of ' $\mathrm{Y}$ ' using sutte indicator," Cogent Econ. Financ., vol. 5, no. 1, 2017.

[33] N. Kurniasih, A. S. Ahmar, D. R. Hidayat, H. Agustin, and E. Rizal, "Forecasting Infant Mortality Rate for China: A Comparison Between $\alpha$-Sutte Indicator, ARIMA, and Holt-Winters," J. Phys. Conf. Ser., vol. 1028, no. 1, p. 012195, 2018.

[34] Ep. E.P. and S. R, "Big data management with machine learning inscribed by domain knowledge for health care," Int. J. Eng. Technol., vol. 6, no. 4, p. 98, Sep. 2017.

[35] J. Shang, P. R. Tadikamalla, L. J. Kirsch, and L. Brown, "A decision support system for managing inventory at GlaxoSmithKline," Decis. Support Syst., vol. 46, no. 1, pp. 1-13, 2008.

[36] P. Karande, E. K. Zavadskas, and S. Chakraborty, "A study on the ranking performance of some MCDM methods for industrial robot selection problems," Int. J. Ind. Eng. Comput., vol. 7, no. 3, pp. 399-422, 2016.

[37] S. H. Zanakis, A. Solomon, N. Wishart, and S. Dublish, "Multiattribute decision making: A simulation comparison of select methods," Eur. J. Oper. Res., vol. 107, no. 3, pp. 507-529, 1998.

[38] A. Zadeh Sarraf, A. Mohaghar, and H. Bazargani, "Developing TOPSIS method using statistical normalization for selecting knowledge management strategies," J. Ind. Eng. Manag., vol. 6, no. 4 , pp. $860-875,2013$. 